\title{
Comparison of Simple vs. Complex Concentrate Mixtures for Dairy Cattle in Puerto Rico: Feeding Lactating Cows Receiving Fair-Quality Forage
}

\author{
Paul F. Randel \\ INTRODUCTION
}

The feeding of dairy cows for most economically efficient milk production depends upon the available forage. Concentrate feeds should be added to the ration only in such manner as to supply nutrients that are deficient in the forage at the lowest possible additional cost. The inclusion in the concentrate mixture of ingredients other than those which will most inexpensively complete the nutritional adequacy of the ration for optimum milk production is not justified economically. Seeking to determine the most economical methods of feeding dairy cattle, the present study was undertaken to determine whether a simple, low-cost concentrate mixture would be nutritionally adequate for lactating cows consuming forage of only fair quality, when compared with a more expensive complex mixture fortified with a great array of specific nutritional factors.

\section{REVIEW OF LITERATURE}

The fact that very simple mixtures of concentrate feeds may support lactation in dairy cows just as well as mixtures containing a wider variety of ingredients, at least when liberal forage is fed, was demonstrated by a series of experiments at the Ohio Agricultural Experiment Station some 20 years ago. During two experiments under pasture conditions $(9)^{2}$, and one experiment under barn-feeding conditions $(8)$, the simple concentrate mixtures consisted of ground shelled corn, soybean-oil meal, and the minerals salt, bonemeal, and limestone, while the complex concentrate mixtures contained three different grains, two different protein supplements, and the same minerals as in the simple mixture, as well as molasses and beet pulp during two of the three experiments. Average daily milk production of the cows on these experiments was in the range of 40 to 50 pounds, and was not significantly affected by the type of concentrate mixture fed. In another experiment to study long-term effects (7), the complex mixture was nearly the same as in the experiments previously mentioned, while ground corn and cobmeal, plus ground oats, were substituted for ground shelled corn

1 Associate Nutritionist, Agricultural Experiment Station, University of Puerto Rico, Substation, Lajas, P.R. The author acknowledges the contribution of Miguel A. Negrón Weber in performing the chemical analyses of the feeds.

2 Italic numbers in parentheses refer to Literature Cited, p. 341. 
in the simple mixture. Over a period of $41 / 2$ years, the average milk productions for 24 lactations on the complex mixture, and 27 lactations on the simple mixture were over 12,000 pounds, and were nearly identical.

In a study at the Texas Agricultural Experiment Station (3), which consisted of a double-reversal trial with 28-day periods, conducted with nine pairs of cows under barn-feeding conditions, a simple concentrate mixture of cottonseed-oil meal, ground ear corn, bonemeal, and salt was compared with a complex mixture containing four different grains, cottonseed-oil meal, dehydrated alfalfa, and minerals. Average daily milk production on either concentrate mixture was about 25 pounds, no difference being found between treatments.

In a North Carolina experiment (10), 48 cows were paired and randomly assigned either to a simple 3 -ingredient concentrate mixture or to a complex 9-ingredient mixture, which was fed from 6 weeks before calving through the lactation period. Average 305-day lactation records of 4-percent fatcorrected milk were in the range of 12,000 pounds, and were practically the same for either treatment.

During a study at the Mississippi Agricultural Experiment Station (2) a simple concentrate mixture consisting of ground ear corn, ground shelled corn, soybean-oil meal, salt, and rock phosphate, in either ground or pelleted form, proved as effective for lactating cows as a complex mixture containing nine energy-supplying ingredients, plus salt, rock phosphate, limestone, trace minerals, and vitamins $A$ and $D$. The forage fed consisted of sorghum silage and alfalfa hay. All three treatments resulted in similar average daily 4-percent fat-corrected milk yields of about 36 pounds.

Studies in New York (4) and Louisiana (6), in addition to the aforementioned Mississippi study, concurred in showing that the supplementation of concentrate mixtures with complex vitamin and mineral combinations is unnecessary and unprofitable under conditions where forage feeding is not severely restricted.

\section{MATERIALS AND METHODS}

This experiment consisted of a double-reversal design feeding trial to compare a simple with a complex concentrate mixture for milk production over the greater part of one lactation.

\section{ANIMALS AND MANAGEMENT}

Twenty-nine cows from the Lajas Substation herd were started on the experiment. However, two cows were lost from the experiment because of acute mastitis, and the data for seven other cows were deleted from the experimental results because five had chronic mastitis sufficiently severe to alter the lactation curve, one had hardware disease, and one suffered 
from excessive nervousness and failure to let down milk completely. Thus a total of 20 cows was left, 10 in each experimental group, from which data were analyzed. Of these 20 cows, 13 were Brown Swiss, and 7 were Holsteins. The cows started on the experiment over a period of 6 months as they became available. They were assigned to one of the two treatments as they reached the 26th day of lactation, by which time it was assumed that peak production had been reached. The two groups were balanced as equally as possible as to breed and age.

The experimental cows were managed the same as the rest of the herd, except for the differences in rations. They were allowed to graze at night, whereas during the day they were maintained in bedded stanchions in a shade-barn. They were milked twice a day at approximately 17 - and 7 hour intervals, and daily milk weights were recorded. Twenty-four-hour samples for determination of milk-fat percentage by the Babcock method were collected monthly.

Each cow was weighed shortly after calving and again on the day following the completion of each experimental period.

\section{RATIONS}

The two experimental rations differed only with respect to the concentrate mixture. The simple concentrate mixture was prepared at the Substation from purchased ingredients. During the period of nearly 14 months that the experiment lasted 13 lots of this mixture were used. The formula was changed slightly among the first four lots in order to take advantage of the least expensive ingredients available, and more nearly to equalize the crude-protein content of the two concentrate mixtures. The percentages of ground shelled corn, soybean-oil meal, wheat bran, and "Ethamol" 3 contained in the 1st, 2nd, 3rd, and 4th through 13th lots were as follows: Lot 1: 55.0, 17.5, 15.0, and 10.0; lot 2: 67.5, 17.5, 0, and 12.5; lot 3: 67.5, $11.25,8.75$, and 10.0; and lots 4 through 13: 75.0, 12.5, 0 , and 10.0. All lots contained 1.5 percent of bonemeal and 1 percent of salt. Fifteen cents was added to the cost of ingredients to allow for handling, grinding, and mixing costs to arrive at an estimate of total cost per 100 pounds of each lot of simple concentrate mixture. The latter ranged from $\$ 3.99$ to $\$ 4.82$ as the cost of ingredients fluctuated.

The complex concentrate mixture selected for use in this experiment was a commercial product, "Fortimax Fitting Feed" 4, guarranteed to contain 14 percent of crude protein, and purchased from Molinos de Puerto Rico,

athamol is the trade name of a commercial feed supplement containing cane molasses, fish solubles, distillers solubles, and ethyl alcohol. Endorsement is not implied.

Endorsement is not implied. 
Inc., Cataño, P.R. However, at one point during the experiment the commercial feed of choice was unavailable, and it was necessary to utilize one lot of a different commercial feed, "Dry and Freshening Dairy Feed", guaranteed to contain 14 percent of crude protein, and purchased from Insular Feed Corp., Mayagüez, P.R.

Both of the commercial feeds had closed formulas. The ingredients of the Fortimax Fitting Feed, of which six lots were used, were as follows: Soybean-oil meal, corn-distillers dried solubles, dried streptomyces-fermentation solubles, rye middlings, corn-gluten meal, dried fermented corn extractives, cornmeal, ground milo, hominy feed, wheat shorts, wheat bran, dehulled soybean meal, dehydrated alfalfa meal, cane molasses, calcium carbonate, dicalcium phosphate, calcium silicate, salt, ferrous carbonate, manganous oxide, zinc oxide, copper oxide, calcium iodate, cobalt carbonate, choline chloride, riboflavin supplement, niacin, choline pantothenate, vitamin B 12 supplement, vitamin A palmitate, vitamin D 2 supplement, vitamin $\mathbf{E}$ supplement, ethoxyquin, butylated hydroanisole, and butylated hydroxytoluene.

The ingredients of the Dry and Freshening Dairy Feed were as follows: soybean-oil meal, ground yellow corn, wheat bran, dried brewers grains, corn-gluten feed, rice bran, hominy feed, wheat gray shorts, molasses, salt, dicalcium phosphate, ground limestone and trace amounts of iodine manganese, iron, copper, and cobalt. The cost of the commercial concentrate mixtures delivered at the Lajas Substation varied among lots from $\$ 4.64$ to $\$ 4.80$ per 100 pounds.

During the first 25 days after calving the cows destined for the experiment were fed the regular herd concentrate mixture in liberal amounts, i.e. at a rate approaching ad libitum. Thereafter, allowances of concentrates were calculated using the Maryland Standards (5); column IV of table A was used because of the fair quality and limited quantity of the forage available, and in accord with the milk-price concentrate-feed cost relationship existing. The concentrate allowance of each individual cow was calculated on the day preceeding her start on the experiment and thereafter every 10 days until she finished it. The cows received either 2 or 3 pounds of concentrates at each milking and the remainder of their allowance in two equal portions while they were in stanchions.

The remainder of the ration consisted of sorghum (Sorghum vulgare) silage, or when this was not available, green chopped sorghum or green chopped merkergrass (Pennisetum purpureum). The harvested forage fed was approximately 25 pounds daily per cow. The pastures grazed by the cows at night were not fertilized or irrigated and consisted mostly of volunteer pajongrass (Andropogon annulatus) and smaller amounts of other species including Guinea grass (Panicum maximum). The quality of the 
pastures varied from fair during periods of high rainfall to poor during periods of drought. The cows were allowed to drink from a watering pool three times daily. Extra salt was not provided.

Samples were taken from each lot of the concentrate mixtures and, periodically, of the harvested forages for proximate analysis by A.O.A.C. procedures (1). No attempt was made to obtain samples of the pasturage consumed by the cows.

\section{STATISTICAL ANALYSIS}

The experimental design was a double reversal with three periods of 80 days each. The first 5 days of each period were considered an adjustment period and the remaining 75 days as the comparison period which provided the data for statistical analysis. All data were analyzed for significance of treatment effects by statistical procedures as outlined by Snedecor (11).

Mastitis was a serious problem during the conduct of this experiment. In addition to the serious cases which caused losses of cows from the experiment, milder cases affected all but 4 of the remaining 20 cows. Milk-production data were deleted for days when production was noticeably affected by mastitis. In such cases the average daily production of a given cow during the 10 days prior to the onset of mastitis was assumed for the days during which production was affected. The average number of days, out of the 225 days of the 3 comparison periods, for which production was affected was 14.7 for 1 experimental group and 9 for the other, for an overall average of 11.85 , or 5.3 percent of the total number of days.

\section{RESULTS}

The simple and the complex concentrate mixtures were very similar in proximate composition (table 1 ). It had been intended that the two mixtures be equal in crude-protein content, but the simple mixture turned out to have a slightly higher level than the complex. The greatest discrepancies occurred in the first two lots of the simple mixture. If these 2 lots are eliminated, the remaining 11 lots of the simple mixture are found to have an average protein content of 15.91 percent, which is very little higher than the average level of the complex mixture. Inspection of the standard deviations (table 1) reveals that the composition of the complex mixture was highly precise, while the simple mixture was subject to somewhat greater variation in composition, in spite of a constant formula for the last 10 lots. The fact that the harvested forages were of mediocre quality is shown by their low dry-matter and crude-protein contents (table 1).

The simple concentrate mixture was apparently more palatable than the complex concentrate mixtures, especially the Fortimax Fitting Feed. The latter was very dusty and several of the experimental cows were reluctant 
to eat it, and occasionally failed to consume all of their allowance of this mixture. The simple mixture was almost always readily consumed.

The average level of milk production obtained from the coivs employed in this experiment was moderate (table 2), even though they were fed concentrates to achieve maximum economically efficient production in accord with the Maryland Standards; this indicates rather low inherent

TABLE 1.-Percentage composition of the proximate constiluents of the various feeds

\begin{tabular}{|c|c|c|c|c|c|c|c|}
\hline \multirow{2}{*}{ Statistic' } & \multirow{2}{*}{$\begin{array}{l}\text { Number } \\
\text { of } \\
\text { samples }\end{array}$} & \multicolumn{6}{|c|}{$\begin{array}{l}\text { Data in percentage, dry-matter basis, for constituents } \\
\text { indicated- }\end{array}$} \\
\hline & & $\begin{array}{c}\text { Dry } \\
\text { matter }\end{array}$ & $\begin{array}{l}\text { Crude } \\
\text { protein }\end{array}$ & $\begin{array}{c}\text { Ether } \\
\text { extract }\end{array}$ & $\begin{array}{c}\text { Crude } \\
\text { fiber }\end{array}$ & Ash & $\mid \begin{array}{c}\text { Nitro- } \\
\text { gen-free } \\
\text { extract }\end{array}$ \\
\hline \multicolumn{8}{|l|}{ Simple concentrate mixture } \\
\hline Mean & 13 & 86.11 & 16.40 & 2.52 & 2.12 & 6.13 & 72.82 \\
\hline Std. dev. & & 1.14 & 1.34 & .69 & .44 & .71 & 1.89 \\
\hline \multicolumn{8}{|l|}{$\begin{array}{l}\text { Complex concentrate mixture } \\
\text { (Fortimax Fitting Feed) }\end{array}$} \\
\hline Mean & 6 & 87.56 & 15.62 & 3.10 & 3.96 & 6.83 & 70.50 \\
\hline Std. dev. & & 1.02 & .38 & .96 & .23 & .70 & .74 \\
\hline \multicolumn{8}{|l|}{$\begin{array}{l}\text { Complex concentrate mixture } \\
\text { (Dry and Freshening Dairy } \\
\text { Feed) }\end{array}$} \\
\hline Single observation & 1 & 93.43 & 16.43 & 3.40 & 4.03 & 7.06 & 69.08 \\
\hline \multicolumn{8}{|l|}{ Sorghum silage } \\
\hline Mean & 7 & 27.26 & 5.86 & 2.54 & 31.25 & 9.86 & 50.49 \\
\hline Std. dev. & & 3.02 & 1.09 & .77 & 6.50 & 1.78 & 4.83 \\
\hline \multicolumn{8}{|l|}{ Green chopped sorghum } \\
\hline Mean & 2 & 20.83 & 11.56 & 3.30 & 29.70 & 9.01 & 46.44 \\
\hline Std. dev. & & 4.42 & 1.22 & .97 & .94 & .11 & 1.49 \\
\hline \multicolumn{8}{|l|}{ Green chopped merkergrass } \\
\hline Mean & 3 & 19.55 & 8.16 & 2.86 & 29.74 & 12.23 & 47.01 \\
\hline Std. dev. & & 5.20 & 1.34 & .48 & 3.48 & 4.53 & 2.22 \\
\hline
\end{tabular}

1 The abbreviation "std. dev." stands for standard deviation.

milk-producing potential. In milk production uncorrected for fat content, there was a highly significant $(P<0.01)$ difference between treatments in favor of the simple concentrate mixture. However, while the cows consuming the simple mixture produced more milk, they produced milk of a slightly lower fat content.

The average milk-fat percentage over the entire experiment was 3.63 for the simple-concentrates treatment and 3.73 for the complex. Milk production expressed on a 4-percent fat-corrected basis did not differ significantly between treatments. There was a tendency for milk-fat per- 
centage to increase as milk production decreased with the advancing stage of lactation; thus the decrease in milk-fat production was less rapid than the decrease in milk production. Mean daily milk-fat production over the entire experiment was almost identical for both treatments. Thus, the simple-concentrates treatment was superior by the criterion of milk production per se, whereas the two treatments were about equal by the other criteria.

TABLE 2.-Lactalional and live-weight responses (pounds) of cows consuming \& different concentrate mixtures

\begin{tabular}{|c|c|c|c|c|}
\hline Response under indicated treatment & Period 1 & Period 2 & Period 3 & $\underset{\text { experiment' }}{\text { Entire }}$ \\
\hline \multicolumn{5}{|l|}{ Mean daily milk production } \\
\hline Simple concentrates & 33.3 & 28.6 & 22.4 & 28.2 \\
\hline Complex concentrates & 32.3 & 26.4 & 23.2 & 27.1 \\
\hline Difference? & 1.0 & 2.2 & -.8 & $1.1^{* *}$ \\
\hline \multicolumn{5}{|c|}{ Mean daily 4-percent $\mathrm{FCM}^{3}$ production } \\
\hline Simple concentrates & 29.6 & 27.5 & 22.1 & 26.6 \\
\hline Complex concentrates & 29.7 & 25.5 & 23.2 & 26.0 \\
\hline Difference ${ }^{2}$ & -.1 & 2.0 & -1.1 & .6 \\
\hline \multicolumn{5}{|l|}{ Mean daily milk-fat production } \\
\hline Simple concentrates & 1.08 & 1.07 & .87 & 1.02 \\
\hline Complex concentrates & 1.12 & 1.00 & .93 & 1.01 \\
\hline Difference $^{2}$ & -.04 & .07 & -.06 & .01 \\
\hline \multicolumn{5}{|l|}{ Mean daily live-weight gain } \\
\hline Simple concentrates & .74 & .47 & .45 & .53 \\
\hline Complex concentrates & .61 & .39 & .31 & .42 \\
\hline Difference $^{2}$ & .13 & .08 & .14 & .11 \\
\hline
\end{tabular}

1 In arriving at means for the entire experiment, period 2 is weighed twice as heavily as are period 1 and period $3 .{ }^{* *}$ Difference statistically significant at $P<0.01$.

${ }^{2}$ Differences among treatments for individual periods are not tested for statistical significance in analyzing a double-reversal-design experiment.

3 The letters FCM stand for fat-corrected milk.

There was a steady increase in live weight of the experimental cows throughout the experiment (table 2), which can be attributed primarily to the fact that 9 of the 20 cows were in their first lactation and were still in the stage of rapid growth. The simple-concentrates treatment resulted in slightly greater increases in live weight, though the difference between treatments was not statistically significant.

As a measure of the efficiency with which the two different concentrate mixtures were utilized for milk production, the ratios of pounds of concentrates consumed per 100 pounds of milk produced and per 100 pounds of 4-percent fat-corrected milk produced were calculated (table 3). According 
to the former criterion, the simple-concentrates treatment proved to be significantly $(P<0.05)$ more efficient, whereas according to the latter criterion, the two treatments were not significantly different. In making these calculations it was necessary to assume that all concentrates offered were consumed, since no weigh-backs of unconsumed feed were made.

This assumption is not entirely realistic, since concentrates were occasionally left uneaten, and the effect of this is probably to penalize the complex-concentrates treatment to some extent. The further assumption that the cows on each treatment derived about equal benefit from the available forage is implicit in the interpretation of these ratios. High levels of concentrates were fed in this experiment as is seen by taking the reciprocals of the ratios, which gives less than 2 as the average pounds of milk produced per pound of concentrates fed.

TABLE 3.-Efficiency of utilization of the 2 different concentrate mixtures for milk production

\begin{tabular}{l|c|c|c}
\hline \multicolumn{1}{c|}{ Treatment } & $\begin{array}{c}\text { Concentrates per 100 } \\
\text { lb. milk1 }\end{array}$ & $\begin{array}{c}\text { Concentrates per 100 } \\
\text { lb. 4-percent FCM }\end{array}$ & $\begin{array}{c}\text { Cost of concentrates per } \\
\text { 100 lb. milk }\end{array}$ \\
\cline { 2 - 3 } & Pounds & Pounds & Dollars \\
Simple concentrates & 55.3 & 58.5 & 2.34 \\
Complex concentrates & 56.8 & 59.1 & 2.67 \\
Difference & $1.5^{*}$ & 0.6 & 0.33 \\
\hline
\end{tabular}

1 * Difference statistically significant $P<0.05$.

2 The letters FCM stand for fat-corrected milk.

As a measure of economic efficiency, the ratio of cost of concentrates consumed per 100 pounds of milk produced was calculated (table 3 ). It was not necessary to correct the milk for fat content, since the milk was sold at a flat rate, regardless of its fat content, as is customary in Puerto Rico. Over the entire experiment the saving in cost of concentrates per 100 pounds of milk produced by using the simple mixture was calculated at $\$ 0.33$. Total feed costs could not be determined from the data obtained in this experiment, but it can be reasonably assumed that the cost of the forage was the same for either treatment. Thus the difference between treatments in income returned above feed costs, should also have been about $\$ 0.33$ per 100 pounds milk produced.

\section{DISCUSSION}

The simple concentrate mixture employed in this experiment was formulated with the considerations in mind of minimizing cost, yet maintaining as high a content of digestible energy as possible, while adjusting the pro- 
tein content so that this mixture would supply adequate, though no surplus of, protein to the cows under the given forage program.

When this simple mixture was compared with a complex mixture, containing a multitude of ingredients supplemented with minerals, vitamins, and antioxidants, the simple mixture showed no sign of being nutritionally inferior. It resulted in lactational responses, efficiency of milk production, and live-weight gains which were as good as, or better than those obtained with the complex mixture. These results support the hypothesis that, under conditions where reasonable levels of forage are fed, even though the forage be of only fair quality, the nutritional factors which must be supplied by the concentrate mixture are primarily energy and protein, minor nutrients being unnecessary where specific deficiencies do not exist. These requirements can be met with very simple concentrate mixtures, as has been shown by this experiment and experiments in several other localities $(2,3,7,8,9,10)$. In addition to being nutritionally adequate, the simple concentrate mixture proved to be more advantageous economically than the costlier complex mixture.

\section{SUMMARY AND CONCLUSIONS}

A double-reversal experiment with 80-day periods, extending from day 26 to day 265 of lactation, was conducted with 2 groups of 10 cows each. The two treatments consisted of two different concentrate mixtures, one of which had a simple formula consisting of ground shelled corn, soybean-oil meal, fortified molasses, bonemeal, and salt, and was prepared at the Substation, while the other was a complex mixture obtained from a commercial source.

Both mixtures contained nearly the same level of crude protein. Concentrate allowances were based upon the Maryland Standards. The remainder of the ration consisted of a moderate amount of sorghum silage, or occasionally green chopped grass, and low-quality pasture.

The simple-concentrate mixture proved to be more palatable than the complex mixture. The lactational response obtained with the simple mixture as compared with the complex mixture was significantly $(P<0.01)$ greater in production of milk uncorrected for fat content, $28.2 \mathrm{vs}$. 27.1 pounds per day, though not significantly different in production of 4-percent fatcorrected milk nor in production of milk fat. The efficiency of utilization of the simple mixture was significantly, $P<0.05$, better for the production of milk uncorrected for fat content, 55.3 vs. 56.8 pounds of concentrates per 100 pounds of milk produced, but not significantly better for the production of 4-percent fat-corrected milk. The cost of concentrates per 100 pounds of milk produced was $\$ 2.34$ for the simple and $\$ 2.67$ for the complex mixture. 
It is concluded that, under conditions of the present experiment, in which forage was limited in quantity and of only fair quality, a simple concentrate nixture formulated to supply digestible energy at a minimum cost is just as adequate nutritionally for lactating cows as a concentrate mixture containing a multitude of different ingredients and supplemented with minerals, vitamins, and antioxidants. It is further concluded that the use of such simple concentrate mixtures prepared at the dairy farm will result in a reduction in feeding costs, provided the operation is large enough to offset the cost of the required machinery. A possible alternative would be the commercial preparation by feed mills of simple concentrate mixtures which could be sold to dairymen at a lower price than the present complex commercial mixtures.

\section{RESUMEN Y CONCLUSIONES}

Se llevó a cabo un experimento del diseño llamado double reversal en períodos de 80 días, que duró desde el día 26 hasta el 265 de la lactancia, con 2 grupos de 10 vacas cada uno. Los dos tratamientos consistieron de dos distintas mezclas de alimentos concentrados, una de las cuales fue una mezcla sencilla de maíz molido, harina de soya, miel fortificada, harina de hueso y sal que se preparó en la misma Subestación, y la otra fue una mezcla compleja que se obtuvo de una fuente comercial. Las dos mezclas tenían casi la misma cantidad de proteina bruta. Las raciones de alimento concentrado se basaron en las Guías de Maryland. El balance de la dieta consistió de una cantidad moderada de ensilaje de millo y de vez en cuando de yerba fresca y pastoreo en pastos de baja calidad.

La mezcla sencilla fue más apetitosa que la compleja. Al compararse el efecto de las dos mezclas sobre la producción de leche, en el caso de la mezcla sencilla la producción fue significativamente mayor (28.2 contra 27.1 libras de leche por día), sin tomar en cuenta el contenido de grasa, aunque no hubo diferencia significativa en la producción al expresarse en en términos de leche con un contenido de grasa de 4 por ciento ni en la cantidad de grasa misma. La eficiencia con que las vacas utilizaron el alimento concentrado fue significativamente mejor $(P<0.05)$ en el caso de la mezcla sencilla en cuanto a su producción de leche sin referencia a su contenido de grasa ( 55.3 contra 56.8 libras de concentrados por cada 100 libras de leche producidas), aunque no lo fue en cuanto a la cantidad expresada en términos de un contenido de grasa de 4 por ciento. El costo del alimento concentrado por cada 100 libras de leche, fue de $\$ 2.34$ en el caso de la mezcla sencilla y $\$ 2.67$ en el caso de la mezcla compleja.

La conclusión que se deduce de estas pruebas, cuando el abastecimiento del forraje disponible es limitado y es éste de mediana calidad, es que desde el punto de vista de la nutrición, tan adecuada es para la producción 
de leche una mezcla sencilla y económica que supla la energía digerible necesaria como una que contenga numerosos ingredientes y que esté suplementada con minerales, vitaminas y antioxidantes. También se concluye que las mezclas sencillas de alimentos concentrados que se preparen en la misma vaquería disminuirá los costos de alimentación, siempre que la empresa sea lo suficientemente grande como para compensar el costo de la mecanización. Otra posible alternativa sería que los molinos comerciales prepararan estas mezclas sencillas y se las vendieran a los ganaderos a un precio inferior al de las complejas mezclas comerciales que ahora se preparan.

\section{LITERATURE CITED}

1. Assoc. Official Agr. Chem., Official Methods of Analysis, 9th. ed., Washington, D.C., 1960.

2. Browing, C. B., Simple grain mixture good in diary test, Miss. Farm Res. 26: 1-7, 1963.

3. Carpentar, S. E., Comparison of a simple and a complex grain mixture for dairy cows. Tex. Agr. Expt. Sta. Prog. Rep. 1993, 1-2, 1957.

4. Chance, C. M., and Loosli, J. K., Effect of a complex mineral-vitamin supplement on milk production, $J$. Dairy Sci. 44: 498-502, 1961.

5. Davis, R. F., Hemken, R. W., Cason, J. L., Vandersall, J. H., and Caskey, C. D., Maryland Feeding Standards for Dairy Cattle. Md. Agr. Expt. Sta. M.P. 481, 1963.

6. Lovell, R. T., and Rusoff, L. L., Effect of a highly fortified vitamin-mineral supplement in high- and low-concentrate rations for dairy cattle, J. Dairy Sci. 46: 1089-93, 1963.

7. Monroe, C. F., and Livezey, W., Simple vs. complex grain mixtures in dairy rations: V, Continuous feeding trial with milking cows, Ohio Agr. Expt. Sta. Bimonthly B. 248: 123-30, 1946.

8. Monroe, C. F., and Krauss, W. E., Simple vs. complex grain mixtures in dairy rations: I, Winter feeding of milking cows, Ohio Agr. Expt. Sta. Bimonthly B. 298: 19-24, 1946.

9. Monroe, C. F., and Krauss, W. E., Simple vs. complex grain mixtures in dairy rations II, Summer feeding to milking cows on pasture, Ohio Agr. Expt. Sta. Bimonthly B. 299: 31-5, 1946.

10. Murley, W. R., Simple vs. complex grain mixture for lactating cows, J. Dairy Sci. 46: 367-8, 1963.

11. Snedecor, G. W., Statistical Methods, 4th ed., Iowa State College Press, Ames, Iowa. 1946. 